\title{
Antibody response to anaerobic coccoid rods in Crohn's disease
}

\author{
K BULL, N MATTHEWS, J RHODES* \\ From the Department of Medical Microbiology, University of Wales College of Medicine, Heath Park, Cardiff, \\ and the *University Hospital of Wales, Heath Park, Cardiff, Wales
}

SUMMARY The IgG and IgM specific antibodies against a panel of 23 anaerobic gut bacteria were examined in Crohn's disease, ulcerative colitis, and healthy controls. Four of the organisms, Bifidobacterium bifidum, Coprococcus comes (ME46), Coprococcus comes (Sp4), and Eubacterium limosum gave abnormal antibody titres in Crohn's disease compared with those of controls. In Crohn's disease specific IgG antibodies to three of the organisms were low and the IgM antibodies were higher than those of controls. IgM antibodies were also raised in ulcerative colitis. Antigenic cross reactivity could be shown between some of these organisms. The possible clinical importance of these abnormal antibody responses to specific organisms is unexplained.

The faecal flora from patients with Crohn's disease differ from those of healthy subjects because they contain large numbers of anaerobic Gram negative rods and Gram positive coccoid rods. ${ }^{1-3}$ Sera from Crohn's disease will also agglutinate certain strains of anaerobic coccoid rods more often than those of matched controls or patients with ulcerative colitis. ${ }^{4-6}$ Previous studies of these antibodies have usually dependend on agglutination of bacteria by human sera. Instead of this relatively crude measurement we used an enzyme linked immunosorbant assay (ELISA) to identify IgG and IgM specific antibodies to the faecal anaerobic bacteria under investigation.

In a pilot study we examined a large number of anaerobic organisms that were tested against sera from Crohn's disease and healthy controls; some of these organisms seemed to differentiate between the groups investigated and were chosen for more detailed investigation.

\section{Material and methods}

INITIAL PILOT STUDY

A group of 23 anaerobes were isolated from the faeces of patients with Crohn's disease and healthy controls and were tested against sera from 14 patients with Crohn's disease and a similar group of healthy controls; enzyme linked immunosorbent assay was used to screen for IgG and IgM antibodies. Of the 23

Accepted for publication 9 April 1986 anaerobes, 10 were coccoid rods, seven cocci, and six rods. The initial measurements of $\mathrm{IgG}$ and $\operatorname{IgM}$ antibody seemed to differentiate between the subject groups for four organisms. The abnormal antibods titres to these bacteria in Crohn's disease were eithe a low IgG or raised IgM value.

\section{MAIN STUDY METHODS}

\section{Bacteria}

We then examined in more detail the four organisms that seemed to differentiate between Crohn's disease and controls. Two of them were obtained from reference laboratories-Bifidobacterium bifidum (NCTC 10471) from the National Collection of Type Cultures (United Kingdom) and Coprococcus comes (ME46) from the Virginia Polytechnic Institute, (United States). ME46 was first described as Eubacterium rectale $^{4}$ and subsequently designated Coprococcus comes. ${ }^{6}$ The remaining two organisms were obtained by anaerobic cultures of fresh faeces on blood agar plates; tentative designations of these organisms were made on the basis of Gram stains, colony morphology, and fermentation characteristics by the Anaerobe-Tek system (table 1).

\section{Patients}

Serum was obtained from 35 patients with Crohn's disease and 25 with ulcerative colitis. The samples were taken from patients attending an outpatient clinic for routine supervision. Diagnosis was based on accepted clinical, radiological, and histological criteria; only patients with clearly defined Crohn's disease 
Table 1 Features used to characterise two anaerobic organisms identified from faeces for further investigation by the ELISA technique

\begin{tabular}{|c|c|c|c|c|c|c|c|}
\hline & \multirow[b]{2}{*}{ Tentative designation } & \multirow[b]{2}{*}{ Morphology } & \multicolumn{4}{|c|}{ Fermentation* } & \multirow[b]{2}{*}{ Other information } \\
\hline & & & Glucose & Lactose & Trehalose & $\overline{\text { Mannitol }}$ & \\
\hline MI & Eubacterium limosum & $\begin{array}{l}\text { Gram positive coccoid } \\
\text { rods in chains of } 3-4\end{array}$ & + & + & - & - & $\begin{array}{l}\text { Bile resistant, from } \\
\text { healthy control }\end{array}$ \\
\hline Sp4 & Coprococcus comes & $\begin{array}{l}\text { Gram positive single } \\
\text { coccoid rods }\end{array}$ & + & - & - & + & $\begin{array}{l}\text { Bile resistant, catalase } \\
\text { positive from patient } \\
\text { with Crohn's disease }\end{array}$ \\
\hline
\end{tabular}

or ulcerative colitis were included. Serum samples from 25 healthy volunteers working in the hospital were obtained as controls. All serum samples were aliquoted and stored at $-70^{\circ} \mathrm{C}$.

\section{ELISA techniques}

Aliquots $(100 \mu \mathrm{l})$ of live bacterial suspension (absorbance $=0.34-0.6$ at $650 \mathrm{~nm}$ ) in carbonate and bicarbonate coating buffer ( $\mathrm{pH} 9 \cdot 6$ ) were added to wells of Dynatech (96 well) microelisa plates and incubated for three hours at $37^{\circ} \mathrm{C}$. Bacteria that were not bound were removed by suction and the plates were washed three times with $0.05 \%$ Tween 20 in isotonic phosphate buffered saline (PBST) (pH 7.3).

The bacteria were then fixed by incubation with $0.2 \%$ glutaraldehyde for five minutes, washed five times with running tap water, treated with $1 \%$ gelatin in phosphate buffered saline for two hours, and washed three times.

Test sera were added, diluted in phosphate buffered saline (usually at $1 / 1000$ ), and incubated for 18 hours at $4^{\circ} \mathrm{C}$. After washing three times with running tap water $100 \mu \mathrm{l}$ of a $1 / 1000$ dilution of alkaline phosphatase conjugated anti-IgG, IgM, or IgA was added and incubated for six hours at room temperature. The plates were then washed three times with tap water followed by the addition of $100 \mu \mathrm{l}$ volumes of alkaline phosphatase substrate (Sigma $1 \mathrm{mg} / \mathrm{ml}$ in glycine buffer $\mathrm{pH} 9 \cdot 8$ ). After one to three hours' incubation at room temperature the absorbance at $405 \mathrm{~nm}$ was measured with a Titertek Multiskan photometer.

Sera were analysed in duplicate with patient and control samples alternating around the plate. In most assays it was necessary to use two microtitre plates, and these were processed at the same time with a standard positive serum on each plate. Interplate variation was $5-10 \%$.

For assays of IgG antibody subclasses the procedure was modified. Monoclonal mouse antibodies (Seward) were used at the following dilutions $(1 / 200$ for $G_{1}, 1 / 400$ for $G_{2}, 1 / 100$ for $G_{3}$, and $1 / 50$ for $G_{4}$ ) for three hours followed by antimouse IgG-alkaline phosphatase conjugate (Sigma) for a further three hours.

\section{ANTIGENIC ASSOCIATION BETWEEN ANAEROBIC} BACTERIA

If antigens are shared by different organisms then absorption of serum with one isolate would also remove antibodies against the second organism. A single sample of serum from a patient with Crohn's disease, which was known to have moderate antibody activity against several of the organisms, was chosen. In addition to activity against $C$ comes ME46, $B$ bifidum, Sp4, and M1, three other anaerobic coccoid rods were included as controls to assess non-specific binding (M3, M4, and F10). The serum sample was diluted 1/500 and absorbed with an equal volume of bacterial suspension $\left(A_{650 \mathrm{~nm}}=1.0\right)$ for one hour at room temperature and four hours at $4^{\circ} \mathrm{C}$ before testing the serum for residual IgG activity using the ELISA technique with anti-IgG conjugate.

\section{OTHER MEASUREMENTS}

In addition to measuring specific antibodies by the ELISA technique, total immunoglobulin concentrations were measured in serum by radial immunodiffusion; the same method was used to measure $\mathrm{C}$ reactive protein.

Concentrations of specific antibodies in the subject groups were compared using the Mann-Whitney U test for non-parametric data.

\section{Results}

\section{ANTIBODY TITRES TO ANAEROBES}

There was a wide range in the concentrations of specific antibodies in each of the three subject groups (figs 1 and 2). The mean concentrations of $\mathrm{IgG}$ specific antibody to the anaerobes ME46, B bifidum, and Sp4 were considerably lower in Crohn's disease than in healthy controls; IgG antibody titres to $C$ comes ME46 and $B$ bifidum were also lower in Crohn's disease than in ulcerative colitis (table 2).

Serum IgM antibodies to two of these organisms, ME46 and Sp4, tended to be higher in Crohn's disease when compared with healthy controls, but they did not differ in patients with ulcerative colitis (table 2 , fig 


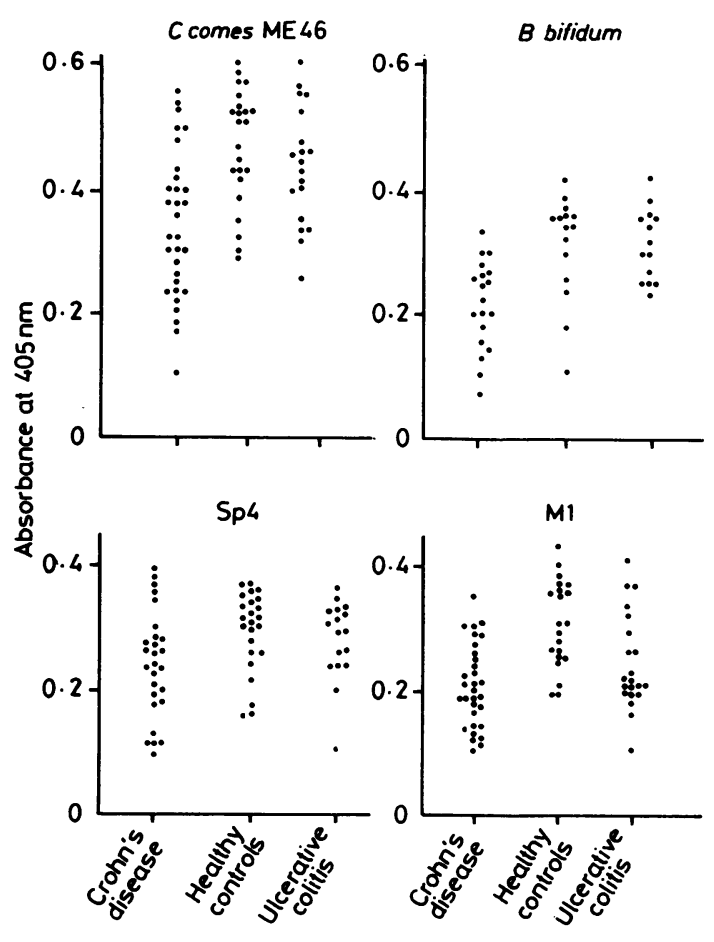

Fig 1 Serum IgG antibodies to $C$ comes ME46 B bifidum, $S p 4$, and MI in sera from patients with Crohn's disease, ulcerative colitis, and from healthy controls.

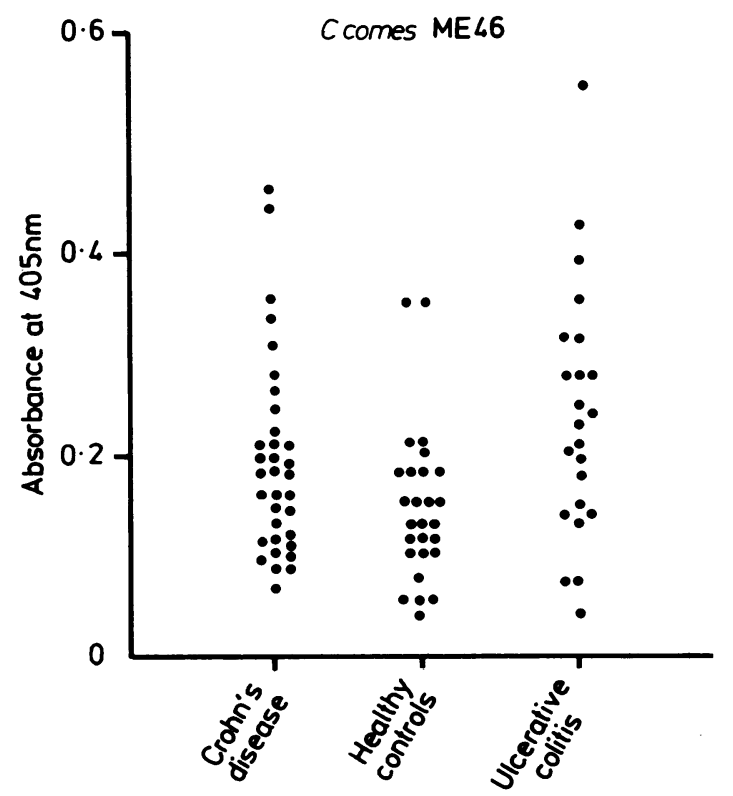

Bull, Matthews, Rhodes

2). There was no difference for the IgM antibodies against the organisms $B$ bifidum, Sp4, and M1.

In Crohn's disease an abnormal antibody titre in one test was often associated with other abnormal titres. An abnormal titre was taken in an arbitrary way for IgG antibodies as less than 0.7 of the mean value for controls and for IgM antibody as more than 1.3 of the mean control value. If a total of five antibody titres only are considered-three of the IgG titres (ME46, Sp4, and B bifidum) and two of the IgM titres ME46 and Sp4 then three or more abnormal values were obtained in seven of 18 with Crohn's disease, one of 16 healthy controls and one of 14 with colitis (table 3).

\section{CORRELATION BETWEEN SPECIFIC ANTIBODY}

CONCENTRATIONS AND TOTAL SERUM

CONCENTRATIONS OF IMMUNOGLOBULINS

AND WITH C REACTIVE PROTEIN

There was no correlation between the total IgG and IgM concentrations in Crohn's disease and the $ᄋ$ specific IgG and IgM antibodies to $C$ comes (ME46), $B$ bifidum, Sp4, or M1. Neither was there any correlation between the serum concentration of $\mathrm{C}$ reactive protein and IgG antibodies to $C$ comes (ME46); $\mathrm{C}$-reactive protein is an acute phase reactant that is often raised in active disease.

SUBCLASSES OF IgG ANTIBODY TO ANAEROBES Antibody against $C$ comes (ME46) could be detecte

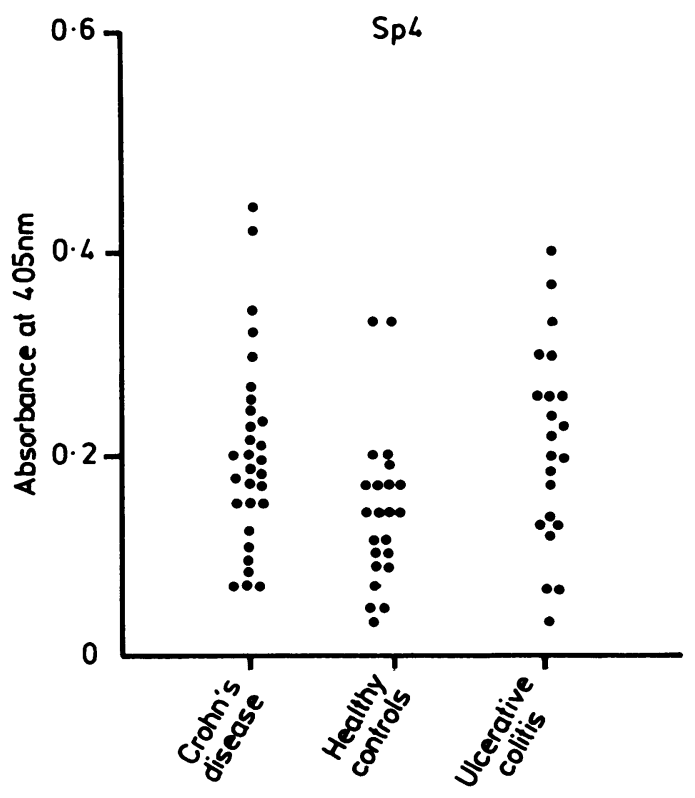

Fig 2 Serum IgM antibodies to C comes and Sp4. Comparison of sera from patients with Crohn's disease with healthy controls and those with ulcerative colitis. 
Table 2 Antibody concentration in subject groups

\begin{tabular}{lllll}
\hline \multirow{2}{*}{ Organism } & \multicolumn{4}{l}{ Mean (SD) antibody concentration (absorbance 450 nm) } \\
\cline { 2 - 5 } & Antibody class & Crohn's disease & Healthy controls & Ulcerative colitis \\
\hline Coprococcus comes ME46 & IgG & $33 \cdot 1(12 \cdot 4)$ & $46 \cdot 4(9 \cdot 8)^{* * * *}$ & $43 \cdot 1(10 \cdot 1)^{* *}$ \\
Bifidobacterium bifidum & IgM & $19 \cdot 7(9 \cdot 5)$ & $15 \cdot 3(7 \cdot 6)$ & $23 \cdot 9(12 \cdot 0)$ \\
Sp4 & IgG & $22 \cdot 1(7 \cdot 6)$ & $32 \cdot 1(8 \cdot 8)^{* *}$ & $32 \cdot 5(6 \cdot 2)^{* * *}$ \\
M1 & IgG & $25 \cdot 4(9 \cdot 0)$ & $31 \cdot 2(6 \cdot 8)^{*}$ & $29 \cdot 4(6 \cdot 6)$ \\
\hline
\end{tabular}

The concentration of IgG and IgM specific antibodies to the anaerobes $C$ comes ME46, B bifidum, Sp4, and M1 measured by ELISA. Results were significantly different from those obtained for Crohn's disease by Mann-Whitney U test: ${ }^{*} p<0.05 ;^{* *}<0.01 ;{ }^{* * *}<0.001$.

Table 3 No of abnormal antibody titres in the three groups of subjects studied

\begin{tabular}{lllllll}
\hline & \multicolumn{5}{c}{ No of sera with abnormal antibody titres in the following number of tests } \\
\cline { 2 - 6 } No of sera from three groups of subjects & 0 & 1 & 2 & 3 & 4 & 5 \\
\hline Crohn's disease 18 & 4 & 1 & 6 & 3 & 2 & 2 \\
Healthy controls 16 & 5 & 8 & 2 & 1 & 0 & 0 \\
Ulcerative colitis 14 & 5 & 1 & 6 & 1 & 0 & 0 \\
\hline
\end{tabular}

Sera from Crohn's disease, healthy controls, and ulcerative colitis were all examined by separate assays for antibody and the number of abnormal assays per sample was noted. Measurements were made of IgG antibody to ME46, Sp4, and $B$ bifidum $($ abnormal $<0 \cdot 7 \times$ mean healthy controls) and IgM to ME46 and Sp4 (abnormal $>1.3 \times$ mean of controls).

in all the four subclasses of $\operatorname{IgG}$ (fig 3). With $\operatorname{IgG}_{1}$, $G_{3}, G_{4}$, the Crohn's disease sera clustered at the lower end of the normal range. With $\mathrm{IgG}_{2}$, many of the Crohn's disease sera gave responses below the normal range and mimicked the overall IgG response. The subclasses of $\mathrm{IgG}$ were not examined with respect to the other organisms.

\section{ANTIGENIC CROSS REACTIVITY BETWEEN \\ ANAEROBIC BACTERIA}

These studies showed strong cross reactivity between $C$ comes (ME46), and B bifidum and less cross reactivity between M1 and $C$ comes (ME46) (table 4). There was also a close antigenic similarity between $C$ comes (ME46) and Sp4.

\section{Discussion}

Abnormal concentrations of antibody to anaerobic organisms only occurred with four of the 23 anaerobes examined, and then only gave clearly abnormal values in about half of the patients. Detailed examination of the abnormality in the antibody response to these four anaerobes ( $C$ comes, ME46, B bifidum, $\mathrm{Sp} 4$, and $\mathrm{M} 1$ ) showed a reduction in the specific IgG antibodies in Crohn's disease, and, to a lesser extent, an increase in IgM specific antibodies. By means of cross absorption studies it was shown that these organisms seemed to be antigenically related, although they were distinguishable on both morphological and cultural grounds.

We have reason to think that the results are valid

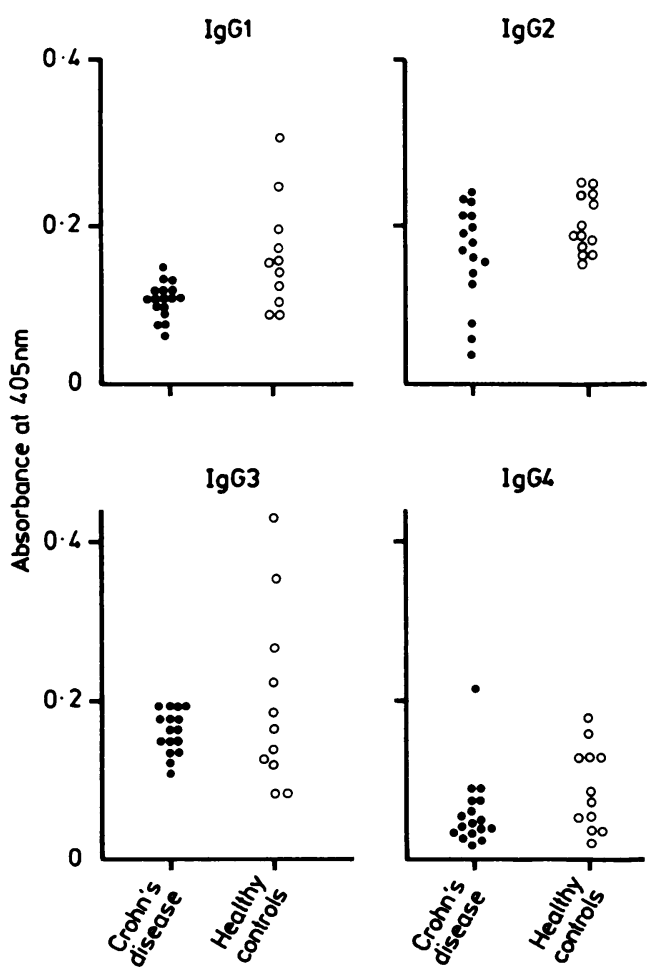

Fig 3 Serum concentrations of IgG antibody for each of four subclasses of IgG against anaerobe C comes (ME46) in sera from patients with Crohn's disease and those from healthy controls. 
Table 4 Antigenic cross reactivity of anaerobic coccoid rods

\begin{tabular}{|c|c|c|c|c|c|c|c|}
\hline \multirow[b]{2}{*}{ Serum absorbed with: } & \multicolumn{7}{|c|}{ Percentage reduction in $\mathrm{Ig} G$ antibody $\left(A_{405} \mathrm{~nm}\right)$ against: } \\
\hline & $C$ comes $M E 46$ & B bifidum & $S p 4$ & $M I$ & $M 3$ & $M 4$ & $F 10$ \\
\hline $\begin{array}{l}\text { C comes ME46 } \\
\text { B bifidum } \\
\text { Sp4 } \\
\text { M1 } \\
\text { M3 } \\
\text { M4 } \\
\text { F10 }\end{array}$ & $\begin{array}{l}81 \\
73 \\
56 \\
44 \\
38 \\
18 \\
26\end{array}$ & $\begin{array}{l}60 \\
92\end{array}$ & 73 & $\begin{array}{l}27 \\
49\end{array}$ & $\begin{array}{l}70 \\
13 \\
30\end{array}$ & 11 & $\begin{array}{r}22 \\
3 \\
77\end{array}$ \\
\hline
\end{tabular}

Antigenic cross reactivity for various anaerobic organisms examined on a single sample of serum from Crohn's disease. High values indicate a high level of antigenic cross reactivity.

rather than due to some non-specific artefact. There was no relation between the titre of the specific antibodies to the relevant organisms and the total immunoglobulin concentrations. It would therefore seem unlikely that the results could be due to non-specific binding of immunoglobulin to the organisms, or ELISA plates. The ELISA technique used is a particularly sensitive method for this kind of work and gave reproducible results.

Our findings confirm those of earlier workers using simple agglutination techniques to identify serum antibodies against various strains of anaerobic coccoid rods. ${ }^{46}$ Agglutination occurs most readily with IgM antibodies which have 10 potential binding sites on the molecules; the increased concentrations of IgM at the expense of IgG observed in Crohn's disease would be expected to favour agglutination. Wensinck's original work, subsequently confirmed by others, suggests that about $60 \%$ of patients with Crohn's disease gave abnormal agglutination tests against a small group of anaerobic organisms. Our detailed investigation of the immunoglobulin class of specific antibody failed to improve the discrimination between Crohn's disease and control groups shown in previous work, and we would not claim that the methods we used have any advantage over previous methods in achieving separation of the subject groups. We do not feel that the test is of value in the diagnosis of Crohn's disease, and it must remain as an immunological oddity.

The results show an unexpected imbalance in the level of antibody response to particular organisms in Crohn's disease compared with the response to other anaerobic organisms present in the faeces. The results cannot simply be interpreted on the basis of a damaged mucosa, which would increase its permeability to penetration by various organisms. There must be some intrinsic abnormality in the host response to particular organisms, or the environment in ulcerated areas of the gut may be particularly favourable towards the growth of organisms that provoke abnormal antibody responses in the serum. ${ }^{7}$ Another possibility is that mucosal damage facilitates penetration by endotoxin and other microbial products from the gut lumen. These may cause polyclonal stimulation of $\overrightarrow{\vec{\omega}}$ B lymphocytes, leading to a non-specific rise in the antibody titres to various micro-organisms. Our $\frac{8}{8}$ results cannot easily be interpreted on this basis $\underset{\varphi}{\omega}$ because the abnormal antibody responses were limited to a select group of enteric organisms.

The abnormal antibody responses may simply be $\overrightarrow{\vec{\omega}}$ epiphenomena, which bear little relevance to the ${ }_{0}$ pathogenesis of Crohn's disease but which may be 음 important in perpetuating the disease process. The apparent clinical benefit that follows treatment with $O$ elemental diets in Crohn's disease may partly be due $\stackrel{0}{\circ}$ to changes in gut flora, which must inevitably follow $\underset{\mathbb{D}}{\mathbb{D}}$ the change in diet. ${ }^{8}$

Dr W E C Moore of Virginia Polytechnic Institue United States, kindly provided the organism ME46-

\section{References}

1 Wensinck $F$. The faecal flora of patients with Crohn's disease. Antonie van Leewwenhoek 1975;41:214-5.

2 Wensinck F. Faecal flora of Crohn's patients: serological $\overrightarrow{\vec{D}}$ differentiation between Crohn's disease and ulcerative colitis. $\frac{3}{3}$ In: Weterman IT, Pena AS, Booth CC, eds. The management of $\frac{\vec{J}}{J}$ Crohn's disease. Amsterdam: Excerpta Medica, 1976:103-6.

3 Wensinck F, Custers-van-Lieshout LMC, Poppelaars-Kustermans PAJ, Schroder AM. The faecal flora of patients with Crohn's disease. J Hyg 1981;87:1-12.

4 Wensinck F, van de Merwe JP. Serum agglutinins to Eubacterium and Petrostreptococcus species in Crohn's and 3 . other disease. J Hyg 1981;87:13-24.

5 Wensinck F, van de Merwe JP, Mayberry JF. An International Study of agglutinins to Eubacterium Peptrostreptococcus and Coprococcus species in Crohn's disease, ulcerative colitis and $\mathrm{O}$ control subjects. Digestion 1983;27:63-9.

6 Auer IO, Roder A, Wensinck JP, van de Merwe JP, Schmidt H. Selected bacterial antibodies in Crohn's disease and ulcerative colitis. Scand J Gastroenterol 1983;18:217-23.

7 Blaser MJ, Miller RA, Lacher J, Singleton JW. Patients with o active Crohn's disease have elevated serum antibodies to anti- N gens of seven enteric bacterial pathogens. Gastroenterology N 1984;87:888-94.

8 O'Morain C, Segal AW, Levi AJ. Elemental diets in treatment of $\widetilde{\sigma}$ acute Crohn's disease. Br Med J 1980;281:1173-9.

Requests for reprints to: Dr J Rhodes, Consultant Physician, University Hospital of Wales, Heath Park, Cardiff CF4 4XW, Wales. 